\title{
Evaluation of acute partial unilateral ureteral obstruction based on the renal venous impedance index in Rabbit: An experimental study
}

\author{
Mahir KAYA ${ }^{1, a}$, Mehmet Alper ÇETINKAYA ${ }^{2, b, \bowtie ~}$ \\ ${ }^{1}$ Medical Imaging Techniques Program, Health Services Vocational College, Akdeniz University, Antalya, Turkey. ${ }^{2}$ Hacettepe \\ University, Laboratory Animal Research and Application Centre, Surgical Research Laboratory, 06100; Sihhiye - Ankara, Turkey. \\ aORCID: 0000-0002-2979-8832, 'bRCID: 0000-0001-5097-6368 \\ ${ }^{\square}$ Corresponding author: macetinkaya@gmail.com \\ Received date: 12.03.2021 - Accepted date: 05.07.2021
}

\begin{abstract}
To investigate the feasibility of the venous impedance index (VII) in the diagnosis of acute partial unilateral ureteral obstruction (APUUO), in this study we aimed to measure and compare changes in intrarenal venous flow and arterial flow. In New Zealand rabbits $(\mathrm{n}=10)$ the left ureter was narrowed by ligation. Doppler ultrasonographic (US) examination of the interlobar arteries and veins in both kidneys was performed preoperatively and 3, 6, 12, 24, and $48 \mathrm{~h}$ after ureteral ligation. Resistive index (RI), RI difference (RI $\Delta$ ) and the RI ratio (RIr), and the VII difference (VII $\Delta$ ) were calculated from RI and VII obtained from the obstructive and nonobstructive kidneys. The RI and VII were postoperatively compared between the left and right kidneys. Although the mean RI for obstructive kidneys was higher than those for nonobstructive kidneys, the difference was only statistically significant at 3 and $24 \mathrm{~h}$ ( $\mathrm{P}=0.007$, and $\mathrm{P}=0.049$, respectively). In all postoperative measurement times, RI $\Delta$ was $\geq 0.08$ and $\mathrm{RIr}$ was $\geq 1.169$, and the mean VII values were significantly lower in the obstructive kidneys than the nonobstructive kidneys ( $\mathrm{P} \leq 0.002)$, and the VII $\Delta$ was equal to or greather than 0.159 . The venous flow was more affected than arterial flow in the obstructive kidney. The renal RI alone was insufficient as a diagnostic criterion. The renal VII $\Delta \geq 0.16$ can be enhanced the diagnostic accuracy of in APUUO if used as a combination of the $\mathrm{RI} \Delta \geq 0.08$ and $\mathrm{RIr} \geq 1.1$.
\end{abstract}

Keywords: Kidney, partial unilateral ureteral obstruction, rabbit, resistive index, venous impedance index.

\section{Tavşanlarda akut parsiyel unilateral üreteral obstruksiyonun renal venöz impedans indeks ile değerlendirilmesi: Deneysel çalışma}

Özet: Akut parsiyel unilateral üreteral obstruksiyonda (APUUO)'nun tanısında venöz impedans indeksin (VII) uygulanabilirliğini araştırmak için bu çalışmada intrarenal venöz akım ve arteriyel akım arasındaki değişiklikleri ölçmeyi ve karşılaştırmayı amaçladık. Yeni Zelanda tavşanlarında $(n=10)$ sol üreter ligasyonla daraltıldı. Her iki böbrekte interlobar arterlerin ve venlerin Doppler ultrasonografik (US) incelemesi preoperatif dönemde ve üreter ligasyonundan sonraki 3., 6., 12., 24. ve 48. saatlerde yapıldı. Resistif indeks (RI) farkı (RI $\Delta$ ), RI oranı (RIr) ve VII farkı (VII $\Delta$ ) obstrüktif ve nonobstrüktif böbreklerden elde edilen RI ve VII'den hesaplandı. RI ve VII, bütün postoperatif ölçüm zamanlarında sol ve sağ böbrekler arasında karşılaştırıldı. Obstrüktif böbrek için ortalama RI, nonobstrüktif böbrekten daha yüksek olmasına rağmen, istatistiki fark sadece 3. ve 24. saatlerde önemliydi (sırasıyla $\mathrm{P}=0,007$ ve $\mathrm{P}=0,049$ ). Tüm postoperatif ölçüm zamanlarında $\mathrm{RI} \Delta \geq 0,08$ ve $\mathrm{RIr} \geq 1,169$, ve ortalama VII değeri obstrüktif böbrekte nonobstrüktif böbrekten daha düşüktü $(\mathrm{P} \leq 0,002)$ ve VII $\Delta$ değeri 0,159 'a eşit veya daha yüksekti. Obstruktif böbrekte venöz akım, arteriyel akımdan daha fazla etkilendi. Tanısal bir kriter olarak renal RI'nin tek başına yetersiz olduğu belirlendi. Renal VII $\Delta \geq 0,16$ değeri, RI $\Delta \geq 0,08$ ve RIr $\geq 1,1$ değerleri ile birlikte kullanılırsa, APUUO'nun tanısal doğruluğu arttırılabilir.

Anahtar sözcükler: Böbrek, parsiyel unilateral üreteral obstrüksiyon, resistif indeks, tavşan, venöz impedans indeks.

\section{Introduction}

Ureteral obstruction (UO) is one of the main pathologies of the urinary tract. The condition may be partial or complete, as well as unilateral or bilateral. If untreated it leads to reversible and irreversible injury to the kidneys and ureters. Etiological factors implicated in renal obstructive parenchymal injury include compromised blood flow, elevated intrapelvic pressure, and increased vasoactive and inflammatory mediators (30). Early diagnosis and treatment are essential if an irreversible injury to the obstructed kidney is to be averted (2).

UO can be diagnosed by several imaging techniques. Radiography and grayscale ultrasonography (US) are 
usually employed in veterinary medicine. The grayscale US can reliably detect collector system dilatation in the kidneys, but it cannot by itself differentiate obstructive from nonobstructive dilatation (20). Changes in perfusions associated with dilatation of the collector system can be assessed using color, power, and duplex Doppler US. Duplex Doppler US examination of a renal arterial tree involves the resistive index (RI) $(19,27)$. The RI basically indicates impedance, defined as downstream as resistance and vessel compliance $(7,16)$. Renal RI is the most widely employed Doppler US index in the evaluation of renal (12, 26) and renovascular (6) diseases, including obstructive uropathy (4), and transplant kidney (23). Platt et al. (20) described renal RI of 0.70 as a good discriminatory value for obstructive uropathy, with an accuracy of $90 \%$. Doppler US has been described as an accurate tool for distinguishing between obstructive and nonobstructive dilatation (20). However, the specificity and sensitivity of renal RI in showing a concurrent increase in resistance and decrease in compliance are poor. Low downstream resistance is usually observed on the venous side of the arterial tree because the veins operate as capacitance vessels. Venous impedance index (VII) is a term applied to the venous side of the vascular tree. Interstitial pressure takes place in acute, complete UO has been linked to a decrease in VII (5).

Although both experimental and clinical studies have investigated the diagnostic value of the RI in UO, there is little focus on the VII value $(5,18,29)$. Only one experimental study has employed the VII value to assess complete UO (24).

The aims of this study were (i) to measure changes in intrarenal venous flow compared to arterial flow in experimentally induced-acute partial unilateral ureteral obstruction (APUUO) and (ii) to investigate the practicability of renal VII value.

\section{Materials and Methods}

The Animal Care Ethics Committee of Akdeniz University, Turkey, approved the study (No: B.30.2.AKD.0.05.07.00). Ten mature male New Zealand rabbits weighing $2.8-3.9 \mathrm{~kg}$ were housed at $25^{\circ} \mathrm{C}$ in a $12-$ $\mathrm{h}$ dark/light cycle. Standard rat chow and free access to water were provided.

Surgical procedure: All animals underwent laparotomy under general anesthesia. The protocol consisted of intramuscular administration of xylazine $\mathrm{HCl}$ (5 mg/kg, Rompun ${ }^{\circledR}$, Bayer, Turkey) and ketamine (35 $\mathrm{mg} / \mathrm{kg}$, Ketalar ${ }^{\circledR}$, Pfizer, Turkey) for pre-anesthesia, followed by induction and maintenance of general anesthesia using inhaled isoflurane $\left(1.5 \%\right.$, Forane ${ }^{\circledR}$, Abbvie, Turkey) and 100\% oxygen in an open system.
Once the left ureter had been exposed and isolated, partial obstruction was induced through the insertion of a 24gauge intravenous catheter $(0.7 \mathrm{~mm}$ diameter $)$ from the external aspect to the interior of the lumen of the left proximal ureter. The ureter was then ligated from the outside the lumen with 3-0 silk suture. The silicon part of the catheter remained outside the lumen (3). All animals received subcutaneous penicillin-G and subcutaneous Butorphanol (0.3mg/kg, Butomidor ${ }^{\circledR}$, Richter Pharma AG. Austria).

Doppler US procedure: Rabbits were placed in the lateral position so that the kidney to be examined. First, the left kidney and then the right kidney were evaluated by means of Doppler US (MINDRAY, DC-6Vet Model, Shenzhen Mindray Bio-medical Electronics Co., LTD, China). Ultrasonographic images were taken using a microconvex, multifrequency probe $(6.5-8.5 \mathrm{MHz})$ in longitudinal and dorsal planes. Color Doppler mode was used to identify intrarenal vessels. Sample volume was placed on the interlobar vascular structure where the best signal was obtained. Afterward, an arterial and venous distinction was made from spectral samples obtained by switching to Duplex Doppler mode. Both the wall filter and sample volume were maintained at minimum levels during the Doppler US examination. Spectral samples were obtained at an angle less than $60^{\circ}$.

Doppler US parameters: The renal RI and VII values were obtained preoperatively and postoperatively at 3, 6, 12, 24 and $48 \mathrm{~h}$ after ureteral ligation from both kidneys. The renal RI [(peak systolic velocity-end diastolic velocity)/peak systolic velocity] was estimated by means of peak systolic velocity and end diastolic velocity following compilation of similar wave forms $(n=3-5)$ from interlobar arteries. Similar to the renal RI, the renal VII [(peakflow signal-least flow signal)/peak flow signal ] was calculated from the spectrum obtained from interlobar veins (Fig 1). The mean renal RI and VII values, obtained from three different points for both kidneys for all measurement times, were calculated and statistically analyzed.

The RI difference (RI $\Delta$ ) and RI ratio (RIr) from the RI values of obstructive and nonobstructive kidneys for all measurement times were calculated: RIA $=R I$ of the obstructive kidney-RI of the nonobstructive kidney and RIr $=R I$ of the obstructive kidney/RI of the nonobstructive kidney. The VII difference (VII $\Delta$ ) from the VII values of obstructive and nonobstructive kidneys for all measurement times were calculated: VIIS $=$ VII of the obstructive kidney-VII of the nonobstructive kidney.

The renal RI> 0.70 (3), RI $\Delta \geq 0.08$ (10), and RIr $\geq 1.10$ (15) were considered as the threshold values for APUUO's Doppler US diagnosis. 


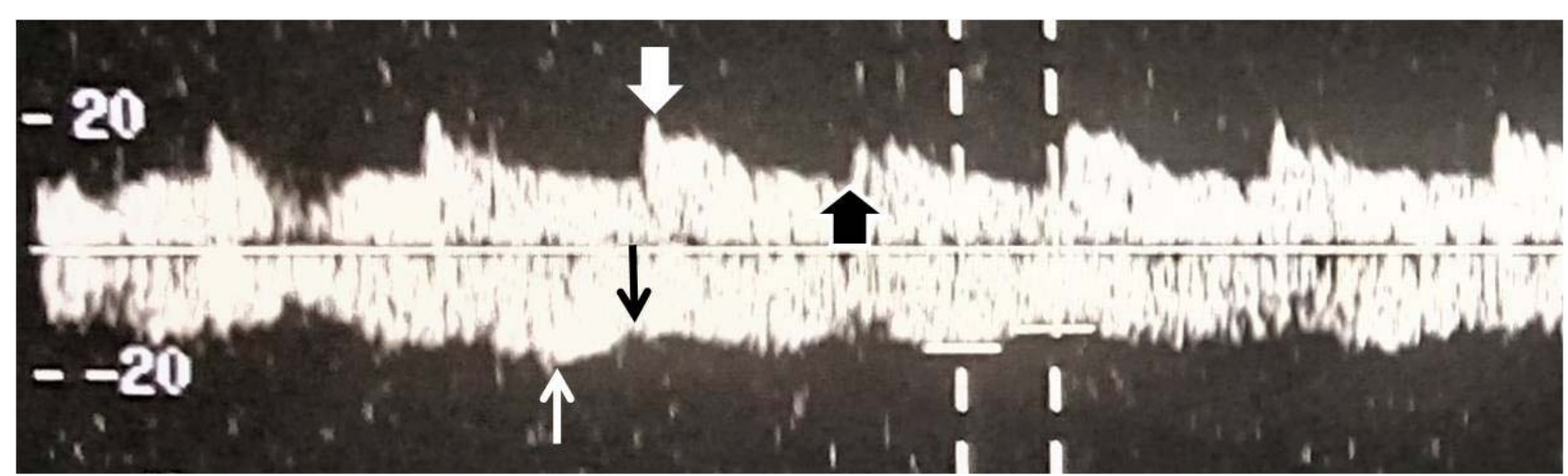

Figure 1. Since the interlobar artery and vein run side by side, arterial and venous Doppler spectra can be obtained simultaneously in the rabbit. The arterial spectrum is viewed as a monophasic wave above the baseline. The wide white arrow points to the peak systolic velocity and the wide black arrow indicates the end-diastolic velocity. In the venous spectrum that appears below the baseline with its wavy flow form, the white arrow indicates the peak flow signal and the black arrow indicates the latest flow signal.

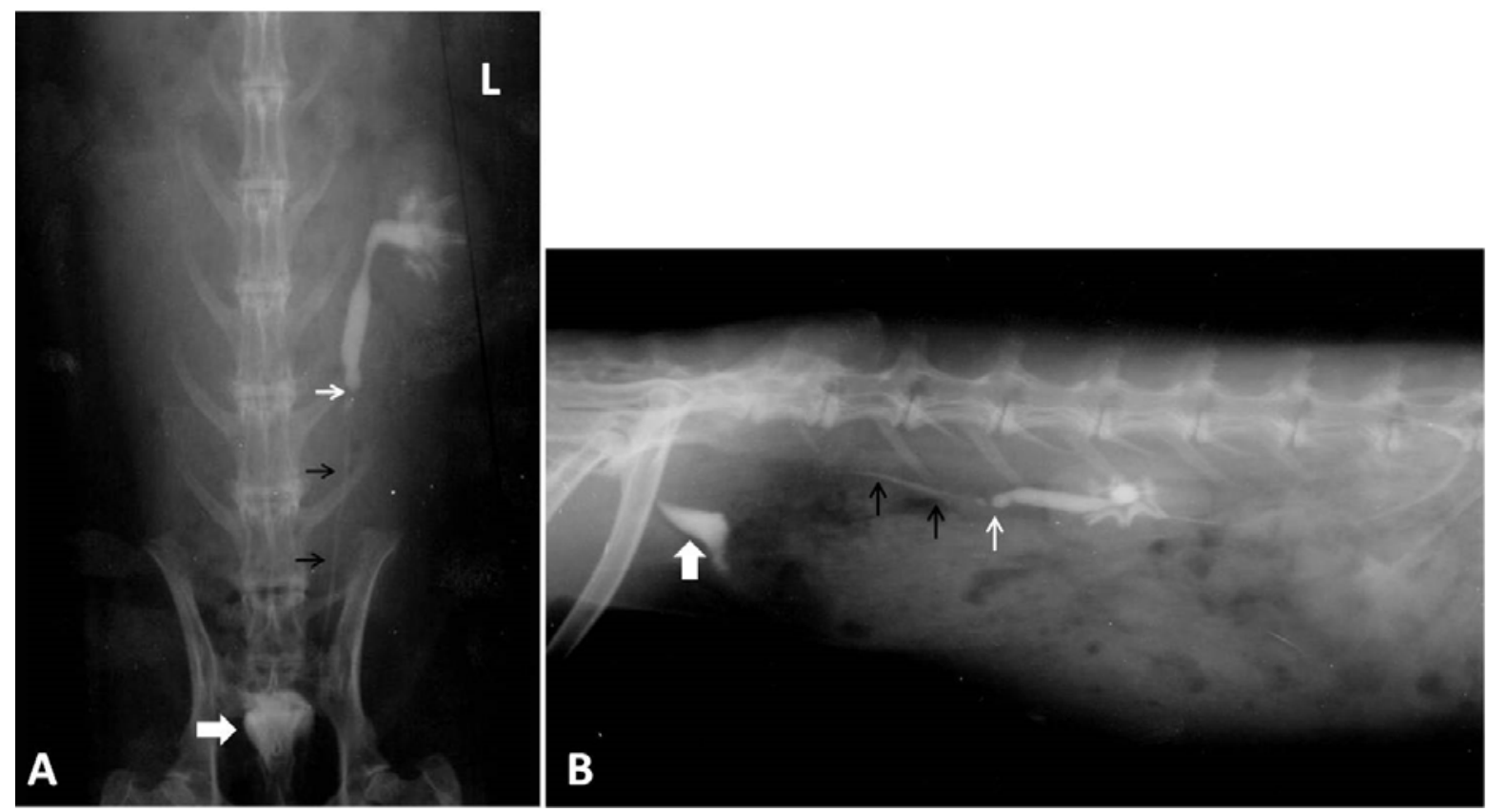

Figure 2. Percutaneous antegrade pyelography was performed to confirm partial unilateral ureteral obstruction showing the left dilated proximal ureter, the partial obstruction side (white arrow), the left distal ureter (black arrows), and bladder (wide arrow) in ventrodorsal (A) and left lateral (B) radiograms.

Confirmation of APUUO: Determination of the dilated renal pelvis and/or proximal ureter, obstruction site, distal ureter, and/or bladder were accepted as confirmation criteria of APUUO for US-guided percutaneous antegrade pyelography (UGPAP). Induction of APUUO was confirmed by UGPAP (13) at $72 \mathrm{~h}$ on all subjects following immobilization with propofol (10 $\mathrm{mg} / \mathrm{kg}, \mathrm{IV}$, Pofol $^{\circledR}$, Sandoz, Turkey) (Fig. 2). UGPAP was only applied to the obstructive (left) kidney. A 25-gauge, 2.5-inch spinal needle was introduced into the renal cortex, perpendicular to the capsule, and advanced into the renal pelvis during ultrasonographic guidance after the kidney was visualized on the dorsal plane via US. The stylet of the spinal needle was removed and some urine was aspirated from pelvis renalis. Non-ionic contrast agent (ultravist 370, Schering, German) was injected into pelvis renalis as much as the amount of aspirated urine, and then the needle was removed. Left lateral and ventrodorsal abdominal X-rays were taken.

Statistical Analysis: Power and sample size analysis calculation (PS version 3.1.2., Vanderbilt University, USA) revealed that replication should be 11 when the mean difference in the renal VII of 0.25 between obstructed and non-obstructed groups to be significant, in a given standard deviation of 0.20 at the alpha error (Type I) of 0.05 and power (beta error or Type 2 error) of 0.95 . Data were subjected to 2-way ANOVA with the repeated measures option was employed to compare the mean RI and mean VII difference between left and right kidneys as well as among time points (SPSS version 21.0, SPSS Inc., Chicago, IL). Results were expressed as mean \pm standard deviation. Statistical significance was set at $\mathrm{P}<0.05$. 


\section{Results}

Renal RI, RIA, and RIr: The mean preoperative RI values were $0.533 \pm 0.09$ and $0.565 \pm 0.12$ for the left and right kidneys $(\mathrm{P}=0.565)$ (Table 1). The postoperative mean RI values decreased in the nonobstructive (right) kidney and increased in the obstructive (left) kidney (Fig. $3)$ compared to their mean preoperative values. However, this change in bilateral postoperative mean RI values was insignificant compared to the mean preoperative RI values. The mean RI in the obstructive kidney did not exceed 0.70 at any postoperative time point. The mean RI values in the obstructive kidneys were higher than those in the nonobstructive kidneys during all postoperative measurements, but the difference between nonobstructive and obstructive kidneys was only statistically significant at 3 and $24 \mathrm{~h}$ postoperation $(\mathrm{P}=0.007$ and $\mathrm{P}=0.049$, respectively).
The RI $\Delta$ was equal to or greater than 0.08 , and the RIr was equal to or greater than 1.169 at all postoperative measurement times.

Renal VII and VIIS: The difference between mean preoperative VII values in the left $(0.596 \pm 0.15)$ and right kidneys $(0.644 \pm 0.12)$ was similar $(\mathrm{P}=0.392)$ (Table 1$)$. The postoperative mean VII values in the obstructive kidney (Fig. 3) were lower than the mean preoperative VII values. This change in the obstructive kidney was significant at other postoperative time points, except for the 3rd and 24th hours $(\mathrm{P} \leq 0.015)$. The difference between preoperative and postoperative VII values of nonobstructive kidneys was statistically insignificant. The mean VII values at all postoperative time points were lower in the obstructive kidney than in the nonobstructive kidney ( $\mathrm{P} \leq 0.002)$. The VII $\Delta$ was equal to or greater than 0.159 at all postoperative measurement times.

Table 1. Renal Doppler indices before and after partial unilateral ureteral obstruction.

\begin{tabular}{|c|c|c|c|c|c|c|c|}
\hline \multirow{3}{*}{$\begin{array}{l}\text { Doppler } \\
\text { Indices }\end{array}$} & \multirow{3}{*}{ Kidney } & \multicolumn{6}{|c|}{ Measurement Times } \\
\hline & & \multirow{2}{*}{ Preop } & \multicolumn{5}{|c|}{ Postop (h) } \\
\hline & & & 3 & 6 & 12 & 24 & 48 \\
\hline \multirow{2}{*}{ RI } & $\mathrm{L}$ & $0.533 \pm 0.09$ & $0.637 \pm 0.07$ & $0.594 \pm 0.07$ & $0.554 \pm 0.08$ & $0.57 \pm 0.07$ & $0.607 \pm 0.06$ \\
\hline & $\mathrm{R}$ & $0.565 \pm 0.12$ & $0.502 \pm 0.07$ & $0.498 \pm 0.09$ & $0.474 \pm 0.08$ & $0.467 \pm 0.1$ & $0.508 \pm 0.07$ \\
\hline$P$ value & & 0.567 & 0.007 & 0.062 & 0.179 & 0.049 & 0.054 \\
\hline RI $\Delta$ & & - & $0.135 \pm 0.08$ & $0.096 \pm 0.03$ & $0.08 \pm 0.07$ & $0.103 \pm 0.04$ & $0.099 \pm 0.05$ \\
\hline RIr & & - & $1.268 \pm 0.1$ & $1.193 \pm 0.07$ & $1.169 \pm 0.11$ & $1.221 \pm 0.14$ & $1.195 \pm 0.09$ \\
\hline \multirow{2}{*}{ VII } & $\mathrm{L}$ & $0.596 \pm 0.15$ & $0.466 \pm 0.13$ & $0.387 \pm 0.12 *$ & $0.353 \pm 0.14 *$ & $0.472 \pm 0.13$ & $0.413 \pm 0.13 *$ \\
\hline & $\mathrm{R}$ & $0.644 \pm 0.12$ & $0.625 \pm 0.13$ & $0.699 \pm 0.15$ & $0.601 \pm 0.19$ & $0.722 \pm 0.14$ & $0.672 \pm 0.15$ \\
\hline Pvalue & & 0.392 & 0.002 & 0.000 & 0.000 & 0.000 & 0.000 \\
\hline VII $\Delta$ & & - & $0.159 \pm 0.1$ & $0.313 \pm 0.13$ & $0.248 \pm 0.15$ & $0.25 \pm 0.13$ & $0.259 \pm 0.14$ \\
\hline
\end{tabular}

Data present as mean \pm standard deviation. h: Hour; L: Left; R: Right; RI: Resistive index; RI $\Delta$ : Resistive index different between obstructive and nonobstructive kidneys. RIr: Resistive index ratio between obstructive and nonobstructive kidneys. VII: Venous impedance index. *Statistical difference between pre and postoperative values, $\mathrm{P}<0.05$.

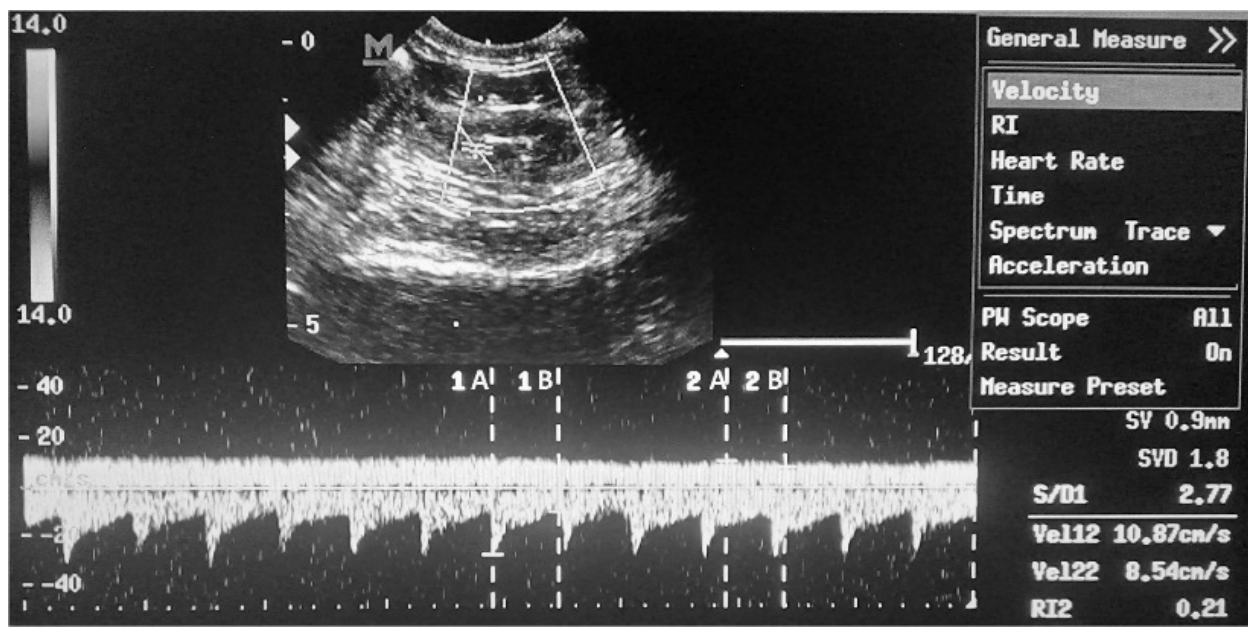

Figure 3. Arterial and venous flow patterns in obstructive (left) kidney at post-operative 6 hours. In obstructive kidney resistive index is 0.58 [peak systolic velocity (1A): $25.52 \mathrm{~cm} / \mathrm{s}$, end diastolic velocity (1B): $10.87 \mathrm{~cm} / \mathrm{s}$ ] and venous impedance index is 0.21 [peak flow signal(2A): $10.87 \mathrm{~cm} / \mathrm{s}$, least flow signal (2B): $8.54 \mathrm{~cm} / \mathrm{s}$ ]. The venous spectrum turned into a predominantly linear flow form. 


\section{Discussion and Conclusion}

UO leads to renal parenchymal injury and even to permanent renal dysfunction unless being treated. Early diagnosis and release of the obstruction are essential if renal functions are to be preserved. Restoration of renal function is inversely correlated to the duration and degree of the obstruction (2).

The renal US is routinely employed for collecting system evaluation (31). The grayscale US is very sensitive in the detection of dilatation of the collecting system. Despite the high sensitivity of grayscale, it is insufficient in the diagnosis of acute $\mathrm{UO}$ due to the subsequent occurrence of pyelocaliectasis under conditions of UO (non-dilated obstruction). Additionally, in hydronephrosis and hydroureter formation associated with other nonobstructive conditions such as pyelonephritis, grayscale may lead to a false diagnosis of obstructive uropathy (11, 21). Specificity of $33 \%$ has been reported for the grayscale US in feline UO under similar conditions (1).

Grayscale US permits accurate visualization of the renal morphology, while Doppler US allows strategically important qualitative and quantitative data. One of these quantitative data is the renal RI value $(11,14)$. In addition to hemodynamic parameters, the renal RI also exhibits a strong correlation with histopathological parameters such as glomerular sclerosis, arteriolosclerosis, interstitial fibrosis/tubular atrophy, and interstitial infiltration (25). This index is only a specific marker of kidney damage and is not an indicator of renal function prognosis. However, it is significantly associated with systemic circulation (8). Although the renal RI is dependent on both renal vascular compliance and resistance, the dependence on resistance is reduced as compliance decreases (7). Experimental and clinical findings have also demonstrated that renal vascular resistance has little effect on the renal RI, but that renal (renal interstitial and venous pressure) and systemic (aortic stiffness and pulse pressure) determinants have a significant effect (28).

Platt et al. (20) first proposed the use of the RI in diagnosing acute urinary obstruction in 1989. Obstructive uropathy can be diagnosed by means of an acute unilateral increase in the renal RI, associated with hydronephrosis, observed 6-48 $\mathrm{h}$ from the onset of symptoms (11). In the present study, although postoperative renal RI values obtained from the obstructive (left) kidney were higher than its preoperative values but insignificant at all times. The mean RI values at postoperative measurement intervals were higher in the obstructive kidney than in the nonobstructive kidney, although only the differences at 3 $\mathrm{h}$ and $24 \mathrm{~h}$ were statistically significant $(\mathrm{P}=0.007$, and $\mathrm{P}=0.049$, respectively).

Our review of the literature revealed no clinical studies assessing UO in cats and dogs using Doppler US and revealing a threshold value for the renal RI. The mean RI values in the obstructive kidney have not exceeded the
0.70 thresholds in studies of experimentally induced partial UO $(13,31)$. The mean RI values in the obstructive kidney did not exceed 0.657 at any postoperative measurement interval in these studies. When a threshold limit for UO of the RI $\Delta>0.10$ (20) was adopted, this was sufficient for diagnosis of APUUO obstruction at only two postoperative time points, while the RI $\Delta>0.06-0.08$ (10) was significant at all measurement intervals (Table 1). Lim et al. (15) evaluated the benefit of the RIr in distinguishing between pediatric obstructive and nonobstructive upper urinary tract dilation. That study described a RIr cut-off value $\geq 1.10$ as a useful parameter for the assessment and follow-up of pediatric unilateral obstructive hydronephrosis. Riahinezhad et al. (22) reported that the RIr $\leq 1.075$ was $82.8 \%$ specific in differentiating nonobstructive hydronephrosis. The RIr $\geq 1.169$ at all postoperative time points in that study.

Low sensitivity and specificity have been reported for the renal RI measurements for the concomitant increase in resistance and decrease in compliance (17). Since the renal RI was problematic in determining acute UO, Bateman and Cuganesan (5) focused on the venous aspect of the renal vascular tree in the diagnosis of acute obstruction. Decreased compliance observed in acute renal obstruction results in weakening of these renal venous signals, the impact on intraparenchymal venous flow being greater than that on arterial flow $(5,9)$. Bateman and Cuganesan (5) reported that, in contrast to the renal RI, the renal VII value is a more sensitive parameter reflecting physiological changes in simultaneously increased resistance and decreased compliance. However, this hypothesis has also been described as not yet proven (9). Similar to the present study, the VII value in the obstructive kidney being lower than in the nonobstructive kidney was also important in previous clinical $(5,18,29)$ and rabbit experimental (24) studies. Combined evaluation of the renal RI and VII values in obstructive uropathy has been reported to improve the diagnostic accuracy of Doppler US $(18,29)$. In the present experimental study, we observed that a decreased VII value in the obstructive kidney compared to the nonobstructive kidney, especially if the VII $\Delta \geq 0.16$, and the RI $\Delta \geq 0.08$, and the RIr $\geq 1.10$ were sufficient for Doppler US diagnosis of APUUO. However, further clinical studies demonstrating a threshold limit, as with the renal RI value, are now needed for the renal VII value to be capable of use as a diagnostic criterion in obstructive uropathy.

In conclusion, the venous flow was more affected than arterial flow in the obstructive kidney, suggesting that the use of $\mathrm{RI} \geq 0.70$ alone as a diagnostic criterion for APUUO was insufficient. A decrease in the VII value in a single kidney may indicate an obstructive kidney. When the VII $\Delta$ value is equal to or greater than 0.16 , taking into account the RI $\Delta \geq 0.08$ and RIr $\geq 1.1$ can increase the diagnostic accuracy of APUUO. 


\section{Financial Support}

This research received no grant from any funding agency/sector.

\section{Ethical Statement}

This study was approved by the Animal Care Ethics Committee of Akdeniz University (No: B.30.2.AKD.0.05.07.00).

\section{Conflict of Interest}

We declare that there is no conflict of interest with any financial organization regarding the material discussed in the manuscript.

\section{References}

1. Adin CA, Herrgesell EJ, Nyland TG, et al (2003): Antegrade pyelography for suspected ureteral obstruction in cats: 11 cases (1995-2001). J Am Vet Med Assoc, 222, 1576-1581.

2. Apoku IN, Ayoola OO, Salako AA, et al (2015): Ultrasound evaluation of obstructive uropathy and its hemodynamic responses in southwest Nigeria. Int Braz J Urol, 41, 556-561.

3. Ayyildiz A, Kaya M, Karaguzel E, et al (2009): Effect of tadalafil on renal resistivity and pulsatility index in partial ureteral obstruction. Urol Int, 83, 75-79.

4. Azam A, Haq A, Beg MB (2013): Role of Renal Arterial Resistive Index (RI) in obstructive uropathy. J Pak Med Assoc, 63, 1511-1515.

5. Bateman GA, Cuganesan R (2002): Renal vein Doppler sonography of obstructive uropathy. Am J Roentgenol, 178, 921-925.

6. Boddi M (2017): Renal ultrasound (and Doppler sonography) in hypertension: An update. Adv Exp Med Biol, 956, 191-208.

7. Bude RO, Rubin JM (1999): Relationship between the resistive index and vascular compliance and resistance. Radiol, 211, 411-417.

8. Di Nicolo P, Granata A (2017): Renal Resistive index: not only kidney. Clin Exp Nephrol, 21, 359-366.

9. Di Nicolo P, Granata A (2018): Renal intraparenchymal resistive index: the ultrasonographic answer to many clinical questions. J Nephrol, 32, 527-538.

10. Granata A, Andrulli S, Bigi MQ, et al (2009): Predictive role of duplex Doppler ultrasonography in the diagnosis of acute renal obstruction in patients with unilateral renal colic. Clin Nephrol, 71, 680-686.

11. Granata A, Zanoli L, Clementi S, et al (2014): Resistive intrarenal index: myth or reality? $\mathrm{Br} \mathrm{J}$ Radiol, 87, 20140004.

12. Grande D, Terlizzese P, Iacoviello M (2017): Role of imaging in the evaluation of renal dysfunction in heart failure patients. World J Nephrol, 6, 123-131.

13. Kaya M, Bumin A, Sen Y, et al (2010): Comparison of Excretory Urography, Ultrasonography-Guided Percutaneous Antegrade Pyelography, and Renal Doppler Ultrasonography in Rabbits with Unilateral Partial Ureteral Obstruction: An Experimental Study. Kafkas Üni Vet Fak Derg, 16, 735-741.
14. Kaya M (2012): The evaluation of renal hemodynamics with Doppler ultrasonography. 1-30. In: Artis, AS (Ed), Hemodynamics - new diagnostic and therapeutic approaches. $1^{\text {st }} \mathrm{ed}$. InTech, Rijeka, Croatia.

15. Lim GY, Jang HS, Lee EJ, et al (1999): Utility of the resistance index ratio in differentiating obstructive from nonobstructive hydronephrosis in children. J Clin Ultrasound, 27, 187-193.

16. Matos I, Azevedo P, Carreira M (2018): Pilot study to evaluate the potential use of the renal resistive index as a preliminary diagnostic tool for chronic kidney disease in cats. J Feline Med Surg, 20, 940-947.

17. Mostbeck GH, Zontsich T, Turetschek K (2001): Ultrasound of the kidney: obstruction and medical diseases. Eur Radiol, 11, 1878-1889.

18. Oktar SH, Cem Y, Ozdemir H, et al (2004): Doppler sonography of renal obstruction: value of venous impedance index measurements. J Ultrasound Med, 23, 929-936.

19. Ostrowska J, Kielbowicz Z, Zaleska-Dorobisz U, et al (2016): Resistive index (RI) obtained in renal interlobar arteries of normal dogs and cats by means of Doppler ultrasonography. Pak Vet J, 36, 45-48.

20. Platt JF, Rubin JM, Ellis JH (1989): Distinction between obstructive and nonobstructive pyelocaliectasis with duplex Doppler sonognaphy. Am J Roentgenol, 153, 997-1000.

21. Platt JF, Rubin JM, Ellis JH (1993): Acute renal obstruction: Evaluation with intrarenal duplex Doppler and conventional US. Radiology, 186, 685-688.

22. Riahinezhad M, Sarrami AH, Gheisari A, et al (2018): How may Doppler indices help in the differentiation of obstructive from nonobstructive hydronephrosis? J Res Med Sci, 23, 76.

23. Schwarz C, Mühlbacher J, Böhming GA, et al (2017): Impact of ultrasound examination shortly after kidney transplantation. Eur Surg, 49, 140-144.

24. Sohn KM, Chung SK, Lee SY (2004): Renal vein Doppler sonography in rabbits with acute ureteral obstruction: usefulness of impedance index of renal vein. $\mathrm{J}$ Korean Radiol Soc, 50, 369-374.

25. Spatola L, Andrulli S (2016): Doppler ultrasound in kidney diseases: a key parameter in clinical long-term follow-up. J Ultrasound, 19, 243-250.

26. Tipisca V, Murino C, Cortese L, et al (2016): Resistive index for kidney evaluation in normal and diseased cats. J Feline Med Surg, 18, 471-475.

27. Tublin ME, Dodd G, Verdile V (1994): Acute renal colic: Diagnosis with duplex Doppler US. Radiol, 193, 697-701.

28. Tublin ME, Bude RO, Platt JF (2003): The resistive index in renal Doppler sonography: where do we stand? Am J Roentgenol, 180, 885-892.

29. Vadana BMK, Pasumarthy A, Penumalli N, et al (2015): Renal venous Doppler study in obstructive uropathy. J Clin Diagn Res, 9, TC13-15.

30. Yasar A, Erdemir F, Parlaktas BS, et al (2013): The effect of carvedilol on serum and tissue oxidative stress parameters in partial ureteral obstruction induced rat model. Kaohsiung J Med Sci, 29, 19-25.

31. Yokoyama H, Tsuji Y (2002): Diuretic Doppler ultrasonography in chronic unilateral partial ureteric obstruction in dog. BJU Int, 90, 100-104. 